\title{
Effects of the Percolation Patterns and the Thickness of Soil Dressing on Reducing Cadmium Uptake and and Yields of Rice Plants (Oryza Sativa L.)
}

\author{
Kiichi Sasaki ${ }^{1}$, Choichi Sasaki ${ }^{2}$, Chihiro Kato ${ }^{2}$, Takeyuki Annaka ${ }^{3}$ and Nobuhiko Matsuyama ${ }^{2}$ \\ 1. The United Graduate School of Agricultural Sciences, Iwate University, Morioka 020-8550, Japan \\ 2. Faculty of Agriculture and Life Science, Hirosaki University, Hirosaki 036-8561, Japan \\ 3. Faculty of Agriculture, Yamagata University, Tsuruoka 997-8555, Japan
}

\begin{abstract}
The objective of this study is to clarify the effects of the thickness of soil dressing, the percolation patterns of plowsole and subsoil on reducing cadmium (Cd) uptake, and growth and yields of rice plants. Six stratified paddy field models, three patterns of soil dressing layer and two percolation patterns were used for the experiments. These models had $12.5 \mathrm{~cm}, 15.0 \mathrm{~cm}$ and $25.0 \mathrm{~cm}$ thickness of soil dressing layer and $15 \mathrm{~cm}$ thickness of underlying polluted soil layer, whose Cd concentration was about $1.81 \mathrm{mg} \cdot \mathrm{kg}^{-1}$. As a result, $\mathrm{Cd}$ concentration of brown rice was lower than $0.04 \mathrm{mg} \cdot \mathrm{kg}^{-1}$ for the models with the close system percolation, while that in the open system percolation models were lower than $0.17 \mathrm{mg} \cdot \mathrm{kg}^{-1}$. When the thickness of soil dressing became lower, Cd concentrations with the open system percolation models showed significantly higher values than those of the other models (5\% of significant level). But any significant difference was not found in the growth and yield among these models. As above mentioned, it was found that $\mathrm{Cd}$ concentration in rice grains was affected by the thickness of soil dressing and percolation patterns.
\end{abstract}

Key words: Cadmium, rice, percolation patterns, soil dressing.

\section{Introduction}

Contaminated crops produced at agricultural lands which are contaminated with heavy metals are threat to the business of farmers and consumers' health. Food safety standards vary with regions or countries. For example, some regions or countries established the maximum level of $\mathrm{Cd}$ in rice as $0.1 \mathrm{mg} \cdot \mathrm{kg}^{-1}$, while the international standard by Codex has been $0.4 \mathrm{mg} \cdot \mathrm{kg}^{-1}$ [1]. It is important and necessary to minimize the contamination level as much as possible and supply safe and trustworthy agricultural products for international trading.

In Japan, the $\mathrm{Cd}$ concentration has caused a very serious health hazard, which is known as the Itai-Itai disease [2]. The Ministry of Agriculture, Forestry and Fishery in Japan recommends $20-30 \mathrm{~cm}$ thickness of

Corresponding author: Choichi Sasaki, Ph.D., main research field: agricultural land engineering. soil dressing, controlling $\mathrm{pH}$ and cultivation under ponding condition as a treatment for reducing the $\mathrm{Cd}$ uptake in rice [3]. The importance of controlling the rhizosphere condition was also pointed by Dong, J. et al. [4].

It was found by Sasaki, C. et al. [5, 6] and Paul, S. K. et al. [7] that $\mathrm{Cd}$ could be absorbed in rice even under ponding condition during the cultivation period depending on the percolation patterns. In actual well-drained paddy fields, water flow in the plowsole and subsoil sometimes is in the same condition as the "open system" percolation, which means that water percolated into plowsole and subsoil under the condition that the soil air in plowsole and subsoil connects with atmosphere. Aeration accompanied with an open system percolation results in oxidation condition of the plowsole and subsoil layers. Therefore, in $\mathrm{Cd}$ contaminated paddy fields, a Cd uptake and an increase of $\mathrm{Cd}$ concentration in brown rice may occur under the 
condition of water flow in the open system since $\mathrm{Cd}$ becomes water-soluble under oxidation condition. Moreover, it was demonstrated by Sasaki, C. et al. [5, 6] and Paul, S. K. et al. [7] that Cd was absorbed from Cd contaminated plowsole and subsoil even in the paddy field remediated with soil dressing. Since the execution of soil dressing usually cost much and securing massive volumes of soil may cause environmental damage, it is important to minimize the thickness of soil dressing and try to enhance the effects of soil dressing as much as possible.

In this study, the effects of variations of thickness of soil dressing on $\mathrm{Cd}$ uptake in brown rice and growth and yields of rice plants were investigated. In order to achieve this objective, the rice growing experiments were conducted with stratified paddy field models which have $12.5 \mathrm{~cm}, 20.0 \mathrm{~cm}$ and $25.0 \mathrm{~cm}$ thickness of soil dressing, contaminated plowsole and subsoil under the condition with water flow in an open and a closed system.

\section{Material and Methods}

\subsection{Soil Properties}

In this study, the same soils and gravel as used by Sasaki, K. et al. [8] was used for the experiments and their physical and chemical properties which are shown in Table 1. Contaminated $\left(1.81 \mathrm{mg} \cdot \mathrm{kg}^{-1}\right)$ and non-contaminated $\left(0.14 \mathrm{mg} \cdot \mathrm{kg}^{-1}\right)$ soil were obtained from the plow layer of actual Cd-contaminated paddy fields in Japan and non-contaminated paddy fields in Kanagi Farm of Hirosaki University, Aomori prefecture, north-eastern part of Japan, respectively. Non-contaminated gravels $\left(0.13 \mathrm{mg} \cdot \mathrm{kg}^{-1}\right)$ collected from Aomori prefecture were used for the lower layer of the experimental models after the fashion of paddy fields near a river.

\subsection{Experimental Design}

Three kinds of stratified paddy field models were used for the experiment: $12.5 \mathrm{~cm}$ thickness of soil dressing, $20.0 \mathrm{~cm}$ thickness of soil dressing and 25.0 $\mathrm{cm}$ thickness of soil dressing (Fig. 1). The same soil was used for plowsole and subsoil in all the models in this experiment. The percolation patterns of plowsole and subsoil used both the open system percolation and the closed system percolation. The O-1 model, O-2 model and O-3 model had $12.5 \mathrm{~cm}, 20 \mathrm{~cm}$ and $25 \mathrm{~cm}$ thickness of soil dressing in the open system percolation, respectively. Similarly, the C-1 model, C-2 model and C-3 model had $12.5 \mathrm{~cm}, 20 \mathrm{~cm}$ and 25 $\mathrm{cm}$ thickness of soil dressing in the closed system percolation, respectively. The percolation patterns were determined by Sasaki, C. [9]. Those models constituted of an iron box $(30 \mathrm{~cm} \times 50 \mathrm{~cm} \times 70 \mathrm{~cm})$ filled with soils of three layers. Plow layer was from 0 $\mathrm{cm}$ to $10 \mathrm{~cm}$ depth (dry density was $1.04-1.18 \mathrm{Mg} \cdot \mathrm{m}^{-3}$ ). Plowsole was from $10.0 \mathrm{~cm}$ to $20.0 \mathrm{~cm}$ depth (dry density at the depth from $10.0 \mathrm{~cm}$ to $12.5 \mathrm{~cm}$ and from $12.5 \mathrm{~cm}$ to $20.0 \mathrm{~cm}$ were $1.23 \mathrm{Mg} \cdot \mathrm{m}^{-3}$ and $0.75-0.89$ $\mathrm{Mg} \cdot \mathrm{m}^{-3}$, respectively). Those soil layers were formed by compaction. Subsoil was from $20.0 \mathrm{~cm}$ to $62.5 \mathrm{~cm}$ depth (dry density of polluted soil, non-polluted soil and gravel was $0.75-0.89 \mathrm{Mg} \cdot \mathrm{m}^{-3}, 0.89 \mathrm{Mg} \cdot \mathrm{m}^{-3}$ and $1.40-1.51 \mathrm{Mg} \cdot \mathrm{m}^{-3}$, respectively). Those soil layers were formed by compaction. The thickness of the polluted soil was $15.0 \mathrm{~cm}$ in all models. The gravel layer was filled beneath the polluted soil layer.

The groundwater level was maintained about 57.5 $\mathrm{cm}$ in the open system percolation models and about $12.5 \mathrm{~cm}-20.0 \mathrm{~cm}$ in the closed system percolation

Table 1 Physical and chemical properties of soils and gravel [8].

\begin{tabular}{|c|c|c|c|c|c|c|c|c|c|c|c|}
\hline & Density & Soil texture & $\mathrm{MgO}$ & $\mathrm{Na}_{2} \mathrm{O}$ & $\mathrm{CaO}$ & $\mathrm{K}_{2} \mathrm{O}$ & $\mathrm{Cd}$ & $\mathrm{T}-\mathrm{C}$ & $\mathrm{T}-\mathrm{N}$ & $\mathrm{C} / \mathrm{N}$ & OM \\
\hline & $\left(\mathrm{g} \cdot \mathrm{cm}^{-3}\right)$ & - & \multicolumn{5}{|c|}{$\left(\mathrm{mg} \cdot \mathrm{kg}^{-1}\right)$} & $(\%)$ & $(\%)$ & - & $(\%)$ \\
\hline Non-contaminated soil & 2.62 & $\mathrm{LiC}$ & 120 & 64 & 400 & 120 & 0.14 & 2.07 & 0.16 & 13.27 & 3.6 \\
\hline Contaminated soil & 2.44 & $\mathrm{CL}$ & 640 & 128 & 2,280 & 288 & 1.81 & 5.30 & 0.39 & 13.57 & 9.1 \\
\hline Gravel & 2.68 & - & 147 & 18 & 539 & 600 & 0.13 & - & 0.00 & - & 0.1 \\
\hline
\end{tabular}




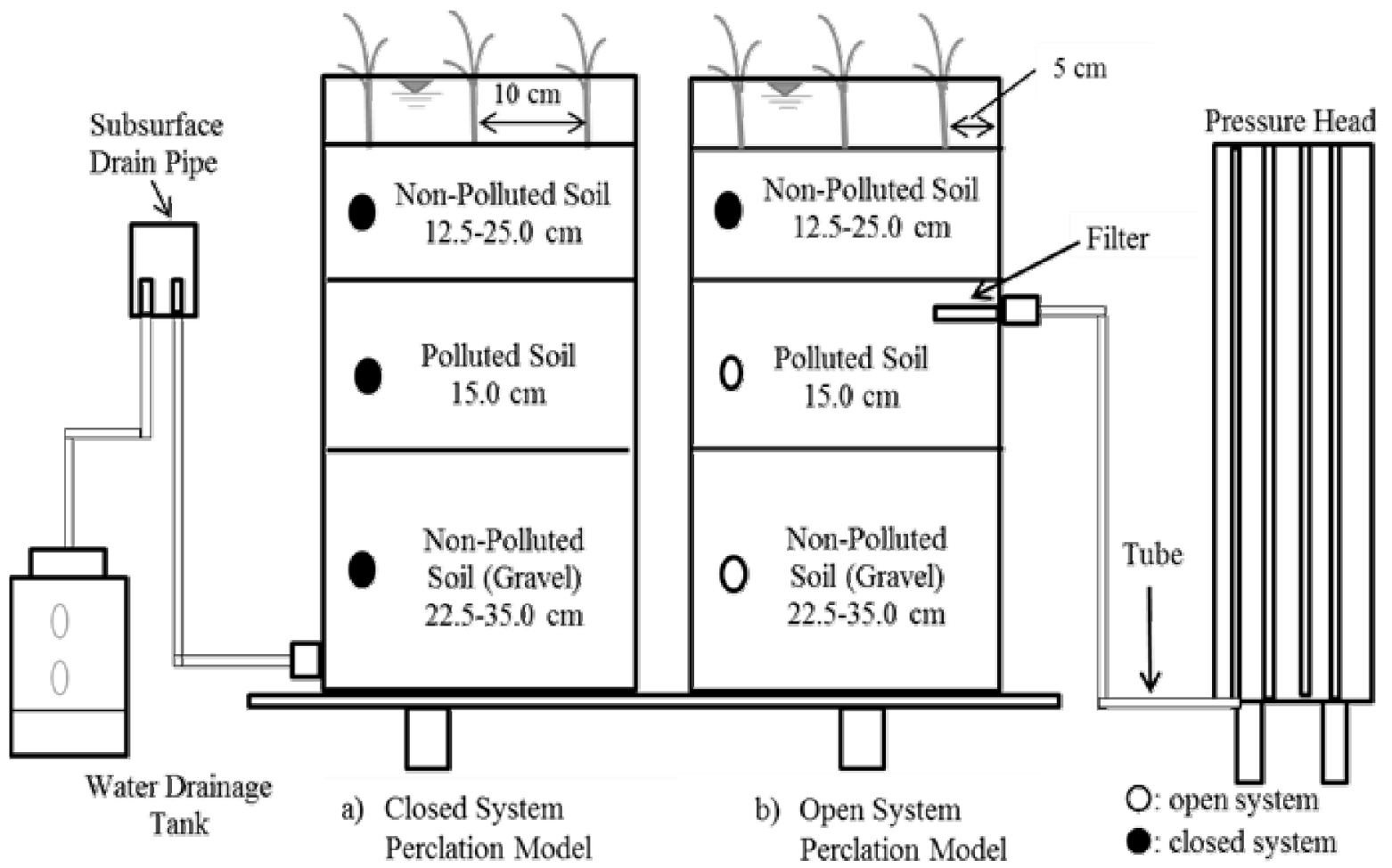

Fig. 1 Layout of the experimental design, soil, rice plants, the equipment and the sampling place of soil which was used for this experiment were the same as used by Sasaki, K. et al. [8].

models. Because the lateral holes in the iron box were blocked by silicon stoppers, the movement of air into the iron box was interrupted in the closed system percolation models. On the other hand, since the lateral holes in the lower part of plowsole and subsoil were open in the open system percolation, the air in the iron box was able to go in and out. After all models were prepared, fifteen paddy seedlings (plant length and leaf stage were from $14.0 \mathrm{~cm}$ to $19.2 \mathrm{~cm}$ and from $5.4 \mathrm{~cm}$ to $6.0 \mathrm{~cm}$ leaves, respectively) called "Tsugaru Roman" were transplanted. Each paddy seedling was transplanted by $10 \mathrm{~cm}$ intervals (the rate of fertilizer application in the plow layer was $2 \mathrm{~g} \mathrm{~N} \cdot \mathrm{box}^{-1}, 2 \mathrm{~g}$ $\mathrm{P}_{2} \mathrm{O}_{5} \cdot$ box $^{-1}$, and $2 \mathrm{~g} \mathrm{~K}_{2} \mathrm{O} \cdot$ box $^{-1}$, respectively, there was no topdressing during the cultivation period). During the cultivation period, a constant water-ponding system was adopted, and mid-summer drainage was not done. Transplanting of paddy seedlings and harvesting were conducted at the end of May and at the end of September, respectively. The experiment of the stratified paddy field model was conducted in a greenhouse of Hirosaki University campus for two years $(2014,2015)$.

\subsection{Measuring Method}

The examination of rice plants such as plant length, leaf stage, the number of stem and panicle, the weight of straw, the number of brown rice and the weight of brown rice was done by the standard of Iwate Agricultural Experimental Station [10]. The quantitative analysis of $\mathrm{Cd}$ concentrations in brown rice and soils was as follows. The samples were treated with $\mathrm{HNO}_{3}$ and $\mathrm{HCl}$ to extract $\mathrm{Cd}$, and then absorbance of extracted solution was measured with atomic absorption spectroscopy [11]. Other measurements were also conducted in standard methods used in Japan. The Oxidation-Reduction Potential (ORP) meter (Central Kagaku Co., Ltd., model UC-203) was used for measuring soil redox potential (Eh). An ORP (Oxidation-Reduction potential sensor was set at each soil layer. The leaf color of rice plants were measured by chlorophyll meter (Konica Minolta, Inc., SPAD-502). 

Uptake and Growth and Yields of Rice Plants (Oryza Sativa L.)

\section{Results and Discussion}

\subsection{Soil Redox Potential (Eh)}

Eh values in each soil layer of O-1, O-2 and O-3 showed a similar change between the transplanting and the harvest. Those of C-1, C-2 and C-3 also showed a similar change. Sasaki, K. et al. [8] reported the results of $\mathrm{O}-1$ and $\mathrm{C}-1$. In this paper, only the results of $\mathrm{O}-2$ and $\mathrm{C}-2$ are shown in Figs. 2 and 3 since the results of O-3 and C-3 were very similar of them. In the open system percolation model-O-2, the plow layer was a reduced layer with the Eh of less than $-100 \mathrm{mV}$, and the plowsole and subsoil were oxidized layers with the Eh of higher than $+400 \mathrm{mV}$ (Fig. 2). On the other hand, in the closed system percolation model-C-2, all layers were reduced layers about 15 days after transplanting with the Eh of less than $-100 \mathrm{mV}$ (Fig. 3).

Oxidation or reduction were judged by using the definition of Yamane, I. [12], which says that a soil layer is oxidized one with an Eh value of higher than $+300 \mathrm{mV}$ and reduced one with an Eh value of less than $+300 \mathrm{mV}$. Since Cd uptake of rice plants is relatively high during three weeks before and after heading, the oxidation-reduction condition of soil layers in this period is critical for the Cd uptake [3]. During three weeks before and after heading, the plowsole and subsoil in the open system percolation model-O-1-O-3 were oxidized (Fig. 2). On the other hand, those layers in the closed system percolation model-C-1-C-3 were reduced during the three weeks (Fig. 3). These results suggested that soluble $\mathrm{Cd}$ affected rice plants in the open system percolation models-O-1-O-3.

\subsection{Cadmium Concentration in Rice Grains}

The Cd concentration in rice grains of each model is shown in Table 2 . The highest value was $0.17 \mathrm{mg} \cdot \mathrm{kg}^{-1}$ in $\mathrm{O}-1$, and the second was $0.10 \mathrm{mg} \cdot \mathrm{kg}^{-1}$ in $\mathrm{O}-2$. For the other four models, $\mathrm{Cd}$ concentrations in rice grains were less than $0.05 \mathrm{mg} \cdot \mathrm{kg}^{-1}$, and showed no significant difference. $\mathrm{Cd}$ concentrations in rice grains in $\mathrm{O}-3$ and $\mathrm{C}-3$, where the thickness of soil dressing was $25.0 \mathrm{~cm}$, were less than $0.06 \mathrm{mg} \cdot \mathrm{kg}^{-1}$, which is the same $\mathrm{Cd}$ concentration in rice grains as produced in non-contaminated paddy fields in Japan [13]. This suggested that with the soil dressing of $25.0 \mathrm{~cm}$ thickness, the $\mathrm{Cd}$ concentration in rice grains could be suppressed safely whether the percolation patterns were the open or the closed system percolation. $\mathrm{Cd}$ concentration of O-1 and O-2 with the open system percolation had significant statistic difference $(5 \%)$ among other four models. $\mathrm{Cd}$ concentration of O-1 also

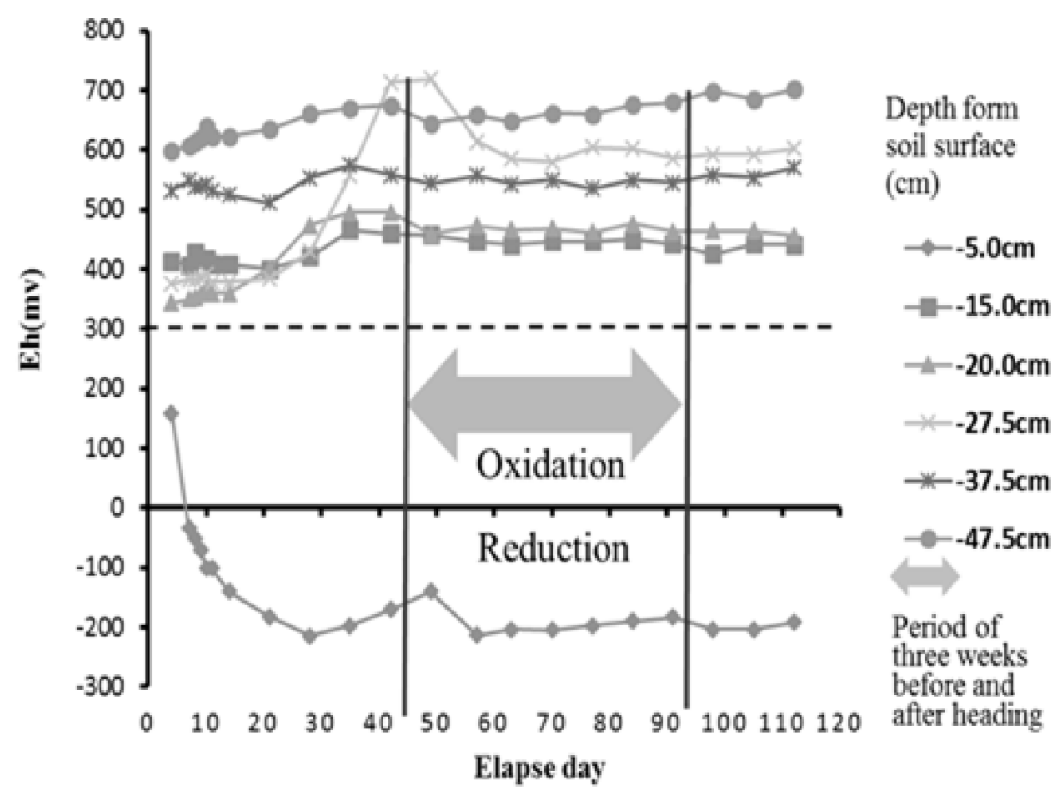

Fig. 2 Oxidation-reduction values in soil layers of the O-2 model. 


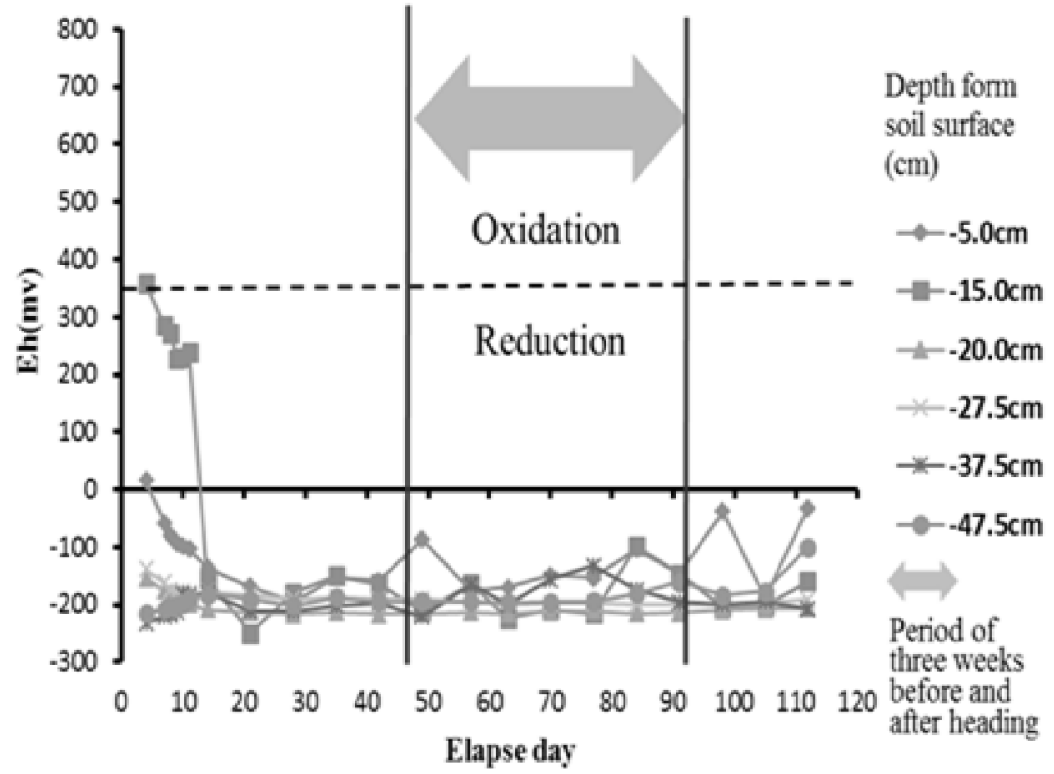

Fig. 3 Oxidation-reduction values in soil layers of the C-2 model.

Table 2 Cd concentration in rice grain, stem and leaves and root.

\begin{tabular}{llll}
\hline Model & $\begin{array}{l}\text { Rice grains } \\
\left(\mathrm{mg} \cdot \mathrm{kg}^{-1}\right) \\
\mathrm{n}=10\end{array}$ & $\begin{array}{l}\text { Stem and leaves } \\
\left(\mathrm{mg} \cdot \mathrm{kg}^{-1}\right)\end{array}$ & $\begin{array}{l}\text { Root of plow layer } \\
\left(\mathrm{mg} \cdot \mathrm{kg}^{-1}\right) \\
\mathrm{n}=1\end{array}$ \\
\hline $\mathrm{O}-1$ & $0.17 \pm 0.05^{\mathrm{a}}$ & $0.86 \pm 0.45^{\mathrm{a}}$ & 3.00 \\
$\mathrm{O}-2$ & $0.10 \pm 0.02^{\mathrm{b}}$ & $0.49 \pm 0.05^{\mathrm{b}}$ & 2.80 \\
$\mathrm{O}-3$ & $0.05 \pm 0.01^{\mathrm{c}}$ & $0.14 \pm 0.03^{\mathrm{c}}$ & 1.70 \\
$\mathrm{C}-1$ & $0.03 \pm 0.01^{\mathrm{c}}$ & $0.24 \pm 0.13^{\mathrm{c}}$ & 3.70 \\
$\mathrm{C}-2$ & $0.04 \pm 0.00^{\mathrm{c}}$ & $0.12 \pm 0.03^{\mathrm{c}}$ & 1.90 \\
$\mathrm{C}-3$ & $0.02 \pm 0.01^{\mathrm{c}}$ & $0.11 \pm 0.02^{\mathrm{c}}$ & 1.90 \\
\hline
\end{tabular}

* Tukey-Kramer test was performed at $5 \%$ level, letter indicates significant difference $(n=10)$, the numerical value of \pm shows standard deviation.

showed significantly higher values than one of O-2. The soil dressing of $20.0 \mathrm{~cm}$ thickness on the $\mathrm{Cd}$ contaminated layer of about $2 \mathrm{mg} \cdot \mathrm{kg}^{-1}$ concentration could result in the risk of not satisfying a strict safety standard for edible rice $\left(0.1 \mathrm{mg} \cdot \mathrm{kg}^{-1}\right)$ such as that of Australia [1]. Also, it was pointed out by Asami, T. [14] that even $\mathrm{Cd}$ concentration of about $0.1 \mathrm{mg} \cdot \mathrm{kg}^{-1}$ in brown rice sometimes would affect human health. Therefore, it was suggested that more than $25.0 \mathrm{~cm}$ soil dressing thickness is favorable to produce safe edible rice in spite of different percolation patterns. $\mathrm{Cd}$ concentrations in the stem and the leaves of O-1 and O-2 were significantly higher than those of four models. But $\mathrm{Cd}$ concentration in the root in plow layer (non-contaminated layer) in six models became
$1.70-3.70 \mathrm{mg} \cdot \mathrm{kg}^{-1}$, so they showed very similar values. This range of $\mathrm{Cd}$ concentration and the order of $\mathrm{Cd}$ concentration are: root $>$ stem and leaves $>$ rice grains which were similar with Sasaki, K. et al. [8].

\subsection{Growth of Rice Plants}

Table 3 shows the growth parameters of rice plants. The average plant length ranged from $92.2 \mathrm{~cm}$ to 102.6 $\mathrm{cm}$ for the six models. The average number of stems ranged from 14.4 to 17.1 , and the weight of dry straw ranged from $14.0 \mathrm{~g}$ to $20.7 \mathrm{~g}$. Percolation patterns and the thickness of soil dressing did not cause any significant differences in the growth parameters mentioned above. Paul, S. K. et al. [7] conducted the related experiments by using the stratified paddy field 
Table 3 Parameters of rice plant growth.

\begin{tabular}{llll}
\hline \multirow{2}{*}{ Model } & Plant length & No. of stems & Weight of dry straw \\
\cline { 2 - 4 } & $(\mathrm{cm})$ & $($ stems/hill $)$ & $(\mathrm{g})$ \\
\hline O-1 & $98.1 \pm 3.6^{\mathrm{a}}$ & $17.1 \pm 2.5^{\mathrm{a}}$ & $17.3 \pm 3.8^{\mathrm{a}}$ \\
O-2 & $102.6 \pm 5.7^{\mathrm{a}}$ & $15.7 \pm 3.8^{\mathrm{a}}$ & $18.2 \pm 6.0^{\mathrm{a}}$ \\
O-3 & $92.2 \pm 1.9^{\mathrm{b}}$ & $14.4 \pm 4.1^{\mathrm{a}}$ & $18.0 \pm 5.8^{\mathrm{a}}$ \\
$\mathrm{C}-1$ & $98.3 \pm 3.5^{\mathrm{ac}}$ & $17.1 \pm 3.2^{\mathrm{a}}$ & $20.7 \pm 6.3^{\mathrm{a}}$ \\
$\mathrm{C}-2$ & $95.5 \pm 3.2^{\mathrm{c}}$ & $16.3 \pm 3.5^{\mathrm{a}}$ & $19.9 \pm 8.8^{\mathrm{a}}$ \\
$\mathrm{C}-3$ & $97.7 \pm 3.2^{\mathrm{c}}$ & $14.9 \pm 2.8^{\mathrm{a}}$ & $14.0 \pm 4.3^{\mathrm{a}}$ \\
\hline
\end{tabular}

* Tukey-Kramer test was performed at $5 \%$ level, letter indicates significant difference $(\mathrm{n}=10)$, the numerical value of \pm shows standard deviation.

models with $12.5 \mathrm{~cm}$ thickness of soil (andisol) dressing and $3.39 \mathrm{mg} \cdot \mathrm{kg}^{-1} \mathrm{Cd}$ contaminated plowsole (10 $\mathrm{cm}$ thickness), and they reported that the growth parameters of the closed system percolation model were significantly higher than those of the open system percolation model. Furthermore, it was reported by Ito, H., and Iimura, K. [15] and Asami, T. et al. [16] that the increase of $\mathrm{Cd}$ concentration in the soil caused the decrease of plant length, the number of stems and weight of dry straw. These are different from the results of this study, which showed no significant effects of $\mathrm{Cd}$ contaminated soil on the growth of rice plants as mentioned above. This can be attributed to such factors as the different soil types for soil dressing, the position of the root system which was mainly in the non-contaminated soil due to soil dressing and the relatively low $\mathrm{Cd}$ concentration of about $2 \mathrm{mg} \cdot \mathrm{kg}^{-1}$.

\subsection{Yield Components of Paddy Rice}

Table 4 shows the yield components of paddy rice both in the open system percolation model and the closed system percolation model. The average number of panicles ranged from 10.4 panicles to 13.4 panicles for the six models. The average weight of brown rice and the average number of brown rice grain ranged from $14.2 \mathrm{~g}$ to $19.2 \mathrm{~g}$ and 774 grains to 1,002 grains, respectively in the two types. The average weight of 1,000 grain weight brown rice ranged from $18.8 \mathrm{~g}$ to $21.7 \mathrm{~g}$ in the two types. There were no significant differences in the yield components between the open system models and the closed system ones, and also no significant differences in them with different thicknesses of soil dressing. However, it was recognized by Paul, S. K. et al. [7] that the yield components of the closed system percolation models were significantly higher than those of the open system percolation models. It was also recognized by Sasaki, C. et al. [5] and Pongpattanasiri, S. et al. [17] that the average number of panicles in the closed system percolation models was significantly higher than those of the open system percolation models. Furthermore, it was reported by Ito, H., and Iimura K. [15] and Asami, T. et al. [16] that an increase of $\mathrm{Cd}$ concentration in the soil caused the decrease of the weight of brown rice. The reason why there were no significant differences in this experiment in the yield components among these six models was thought to be the effects of soil dressing and the relatively low $\mathrm{Cd}$ concentration of less than about $2 \mathrm{mg} \cdot \mathrm{kg}^{-1}$ in the plowsole and the subsoil.

Transfer prevention of nutrients from stems and leaves to grains (i.e., weight of brown rice/weight of dry straws and leaves) was not recognized in this experiment because of those values of transfer prevention became nearly equal to 1 (obtained range with 0.89-1.07). Transfer prevention values of Paul, S. K. et al. [7] were about 1.05. But it was reported by Sasaki, C. et al. [6] that transfer prevention values became $20 \%$ higher in the closed system percolation models. As a result, it was judged that transfer prevention in this condition did not occur because of the existence of soil dressing. 
Table 4 Parameter of rice yield.

\begin{tabular}{lllll}
\hline Model & $\begin{array}{l}\text { No. of Paniles } \\
(\text { Panicles/hill })\end{array}$ & $\begin{array}{l}\text { Weight of brown rice grain per } \\
\text { unit hill } \\
(\mathrm{g})\end{array}$ & $\begin{array}{l}\text { Number of brown rice grain per } \\
\text { unit hill } \\
(\text { No. of grains })\end{array}$ & $\begin{array}{l}1,000 \text { grain weight of brown rice } \\
(\mathrm{g})\end{array}$ \\
\hline $\mathrm{O}-1$ & $12.9 \pm 2.5^{\mathrm{a}}$ & $17.1 \pm 2.5^{\mathrm{a}}$ & $790 \pm 189^{\mathrm{a}}$ & $18.8 \pm 0.4^{\mathrm{a}}$ \\
$\mathrm{O}-2$ & $12.9 \pm 3.3^{\mathrm{a}}$ & $15.7 \pm 3.8^{\mathrm{a}}$ & $1,002 \pm 319^{\mathrm{a}}$ & $21.4 \pm 0.6^{\mathrm{b}}$ \\
$\mathrm{O}-3$ & $10.4 \pm 2.6^{\mathrm{a}}$ & $14.4 \pm 4.1^{\mathrm{a}}$ & $918 \pm 266^{\mathrm{a}}$ & $21.6 \pm 0.9^{\mathrm{b}}$ \\
$\mathrm{C}-1$ & $13.2 \pm 2.7^{\mathrm{a}}$ & $17.1 \pm 3.2^{\mathrm{a}}$ & $938 \pm 260^{\mathrm{a}}$ & $19.4 \pm 1.1^{\mathrm{a}}$ \\
$\mathrm{C}-2$ & $13.4 \pm 3.1^{\mathrm{a}}$ & $16.3 \pm 3.5^{\mathrm{a}}$ & $976 \pm 283^{\mathrm{a}}$ & $21.7 \pm 0.6^{\mathrm{b}}$ \\
$\mathrm{C}-3$ & $13.0 \pm 3.0^{\mathrm{a}}$ & $14.9 \pm 2.8^{\mathrm{a}}$ & $774 \pm 269^{\mathrm{a}}$ & $21.5 \pm 0.5^{\mathrm{b}}$ \\
\hline
\end{tabular}

* Tukey-Kramer test was performed at $5 \%$ level, letter indicates significantdifference $(\mathrm{n}=10)$, the numerical value of \pm shows standard deviation.

\section{Conclusion}

As the countermeasures against Cd-polluted paddy fields, rice growing experiment was conducted with six models of stratified paddy fields that had ponding during cultivation. These models were divided into three different thicknesses of soil dressing $(12.5 \mathrm{~cm}$, $20.0 \mathrm{~cm}$ and $25.0 \mathrm{~cm}$ ), and also into two different percolation patterns - the closed system percolation and the open system percolation of the plowsole and the subsoil. Those models all had a contaminated layer in them of Cd concentration $1.81 \mathrm{mg} \cdot \mathrm{kg}^{-1}$ and $15 \mathrm{~cm}$ thickness.

The results were that the open system percolation layers became an oxidation condition and that the closed system percolation layers became a reduction condition. $\mathrm{Cd}$ concentration in brown rice was significantly lower when the thickness of soil dressing was $25.0 \mathrm{~cm}$ than that was $12.5 \mathrm{~cm}$ and $20.0 \mathrm{~cm}$ under the condition of open system percolation. Consequently, it was found that less than $20.0 \mathrm{~cm}$ soil dressing models with the open system percolation could not satisfy the strict standard of $\mathrm{Cd}$ concentration of brown rice in other countries. But it was not recognized statistical significant difference in growth and yield in rice plants with those models.

\section{Acknowledgement}

The authors would like to thank Jinhun Fan, Songtao Li, Hideki Takahashi and Tomoaki Hasegawa for their cooperations throughout this research. In addition, the authors appreciate the support of this research by both Grants-in-Aid for Scientific Research (Challenging exploratory research; 26660188) and grants from the Faculty of Agriculture and Life Science, Hirosaki University.

\section{References}

[1] The Ministry of Agriculture, Forestry and Fisheries of Japan. 2015. "Profile Sheet of Food Safety (Chemical Substances)." Accessed April 1, 2016. http://www.maff.go.jp/j/syouan/seisaku/risk_analysis/prio rity/pdf/150803_cd.pdf.

[2] Kobayashi, J. 1978. "Pollution by Cadmium and the Itai-Itai Disease in Japan." In Toxicity of Heavy Metals in the Environment, edited by Oehme, F. W. New York: Marcel Dekker.

[3] The Ministry of Agriculture, Forestry and Fisheries of Japan. 2005. "Techinical Manual of Suppressing Cadmium Absorption of Paddy Rice." Accessed April 1, 2016. http://www.maff.go.jp/j/syouan/nouan/kome/ k_cd/taisaku/pdf/d3.pdf.

[4] Dong, J., Mao, W. H., Zang, G. P., Wu, F. B., and Cai, Y. 2007. "Root Excretion and Plant Tolerance to Cadmium Toxicity-A Review." Plant Soil Environment 53 (5): 193-200.

[5] Sasaki, C., Matuyama, N., Kubota, M., Noda, K., and Kato, K. 2010. "Influence of a Percolation Pattern on the Cadmium Concentration, the Growth and the Yield of Rice Plants in Cadmium Polluted Paddy Fields with Soil Dressing." Transaction of the Japanese Society of Irrigation, Drainage and Reclamation Engineering 268: 23-30.

[6] Sasaki, C., Matuyama, N., Kubota, M., Noda, K., and Kadono, M. 2012. "Influence of Difference in Cadmium Polluted Thickness on the Cadmium Concentration, the 
Growth and the Yield of Rice Plants in Cadmium Polluted Paddy Fields." Transaction of the Japanese Society of Irrigation, Drainage and Reclamation Engineering 279: 13-20.

[7] Paul, S. K., Sasaki, C., Matuyama, N., Noda, K., and Mitra, B. K. 2011. "Influence of Percolation Patterns on Growth and Yield of Rice Plants and Uptake of Cadmium from Polluted Paddy Fields Using Soil Dressing Models." Pedologist 222-229.

[8] Sasaki, K., Sasaki, C., Kato, C., Endo, A., Annaka, T. and Moritani, S. et al. 2016. "Studies on Reducing Cadmium Uptake of Rice Plants (Oryza Sativa L.) by Both Soil Dressing and Mixing Tillage.” Presented at International Society of Environmental and Rural Development.

[9] Sasaki, C. 1992. "On the Dissolved Oxygen Content in Seepage Water of Open and the Closed System Percolation in a Stratified Soil Column." Transaction of the Japanese Society of Irrigation, Drainage and Reclamation Engineering 159: 65-71.

[10] Iwate Agricultural Experimental Station. 1981. "Standard Investigation Method of Field Crops." Accessed April 1, 2016. http://www2.pref.iwate.jp/ hp2088/library/ chousa/chousa_index.html.

[11] The Ministry of Agriculture, Forestry and Fisheries of Japan. 1979. "The Foundation of Environmental Paddy Field and Investigation of Paddy Field, Water Quality and
Crop Analysis Method." In National Conference of Paddy Field Preservation 113-115.

[12] Yamane, I. 1982. Soil Science of Paddy Field. Tokyo: Nobunkyo.

[13] The Ministry of Agriculture, Forestry and Fisheries of Japan. 2015. "Cadmium Concentration in Domestic and Foreign Rice." Accessed April 1, 2016. http://www. maff.go.jp/j/syouan/nouan/kome/k_cd/kaisetu/gaiyo2/ind ex.html.

[14] Asami, T. 2010. Toxic Metal Concentration in Japan. Tokyo: Agune Technology Center Ltd..

[15] Ito, H., and Iimura, K. 1976. "The Absorption and Translation of Cadmium in Rice Plants and Its Influence on Their Growth, in Comparison with Zinc." Bultein of the Hokuriku Agricultural Experiment Station 19: 71-139.

[16] Asami, T., Orikasa, K., and Kubota, M. 1995. "Influence of Water Management on the Uptake of Cadmium, Zinc, Lead and Copper with Rice under Futyu Soil and Annaka Soil Polluted Heavy Metal.” People and Environment 21 (2): 54-60.

[17] Pongpattanasiri, S., Sasaki, C., Matsuyama, N., Tonouchi, A., and Noda, K. 2005. "Influence of Percolation Pattern on Removal of Soluble Elements in Downward Water and Cadmium Transfer Using a Stratified Paddy Field Model." Journal of the Japanese Society of Soil Physics 101: 17-26. 